\title{
INTERNATIONAL POSITION AND EUROPEAN INTEGRATION OF THE WESTERN BALKANS COUNTRIES
}

\author{
Academician PhD Slobodan Neskovic \\ University Business Academy in Novi Sad, FIMEK; \\ Professor HonorsCause St. Cyril and St. Methodius,
}

\begin{abstract}
The sub-region of the Western Balkans includes Serbia, Montenegro, Bosnia and Herzegovina, Albania and Northern Macedonia. The international position of these countries is different and depends on socio-economic development, political and security entities and elements. The processes of European integration of individual countries are different, since they are in different phases. This is determined by procedural acts related to Euro integration and open chapters of the nomenclature. In addition, Serbia, Montenegro and Albania have the status of official candidates for admission to the European Union. Due to the permanently expressed security challenges, risks and threats in theory and practice, it is called "barrel with gunpowder". Therefore, this space marks one of the most attractive topics for all social phenomena researchers. The aforementioned micro region of the region of Southeast Europe implies the formulation of authentic foreign policy and security concepts of influential actors in the international community. The article deals with international, foreign political and wider social implications of the Western Balkan countries, inclusion in the strategic concept of Euro integration.
\end{abstract}

Key words: Western Balkans, international position, European integrations, state, security, politics, European Union.

\section{INTRODUCTION}

Geopolitical, military and economic relations in the modern world are a sign of conflict of interest that defines geopolitics, and therefore a security image of the world. The struggle of interests today is being guided by sophisticated economic and military means, and any study of global relations must be studied by international subjects and their relations. We can monitor world and regional security through the roles of some important actors of the order (the most powerful and largest states in the world, that is, the world's major centers of power) and their interactions. Modern centers of power in the world are the United States, the European Union and the Russian Federation, and their mutual relations are the main factors influencing contemporary international, economic, military and geopolitical relations. It is therefore important to explore these relationships and see what is good in them and what is bad, and what the development trends are. Modern world security is marked by globalization, the shifts of global actors in the world order, attempts to establish global governance and universal conventions. 
The paper examines the basic characteristics of the position, national interests and economic, military and foreign policy orientations of the European Union and their impact on the region of the Western Balkans. A review is also made of the security strategy and strategy of this entity's performance in the Western Balkans, through the prism of the impact of that strategy on the security of this region. The regional security of the Western Balkan countries is determined by their individual foreign policies. Accessing these countries to the European Union is one of the main priorities of each of them. This implies the need for future harmonization of the foreign policy of these countries with the Common Foreign and Security Policy (CFSP). This commitment was also accepted thanks to the signing of an agreement on the stabilization of these countries with the European Union. Also, the promotion of the position of the Western Balkan countries within international organizations of a global and regional character can be encouraged through mutual support and lobbying in their work. It is very important for the peace and prosperity of this region to create opportunities for bilateral / multilateral regional partnerships.

\section{THE INTERNATIONAL POSITION OF THE WESTERN BALKANS COUNTRIES}

The Western Balkans is the date of a newer date and appears as a neutral geopolitical determinant after the Cold War and the war in the former Yugoslavia. The Western Balkans is primarily a political category and marks mainly all Southeast European countries that are not members of the European Union. ${ }^{1}$ This is the beginning of the 21 st century. century is used to identify, first and foremost, the territories of the Balkan states. These are: Serbia, Bosnia and Herzegovina, Montenegro, Macedonia and Albania (since Croatia became a full member of the EU in 2013). Also, this area has been through the history of the territory of the biggest disputes and conflicts in Europe. Over the last 40 years, the space of the Western Balkans is the only place in Europe where war is being waged, while all other countries resolve their misunderstandings with the negotiations. The reason for these conflicts is the centuries-old struggle for territories, and the diverse national, ethnic and religious affiliation of the people.

While the aspirations for unification appeared in Europe, the Western Balkans had a bloody clash at the end of the 20th century. This war took place between the countries of the former Yugoslavia, which lasted for 5 years, and later continued, with the bombing of Serbia and the conflicts in Kosovo. By bringing the Balkan countries closer to the European Union, security risks for war conflicts are also being reduced, and all nations, republics and entities are increasingly resorting to compromises and negotiations at state levels. Such a shift can also be seen within the individual issues of each state, because to date we do not have clearly outlined borders within individual Balkan states where there is still a great desire for secession and autonomy of certain regions in which national issues have not been resolved to date. After the

\footnotetext{
${ }^{1}$ Nešković, S., Ketin, S., Šećerov, P., Đelić, T., A., International Politics and Ecology: Special Focus to the Protection of Air, Frensenius Environmental Bulletin - FEB, Vol. 27. No 11 / 2018, p. 7545.
} 
end of the Cold War and the comparative commencement of the process of disintegration of the former Socialist Federal Republic of Yugoslavia, the newly emerging states on its soil began with the redefinition of their own foreign policy. The states created by Yugoslavia, during their first years of independence, distanced themselves from the foreign policy was conducted between 1945 and 1990, although during the first decade of independence, most of these countries did not have the basicstrategic documents in the field of foreign policy.

Poor legacy of armed conflicts in post-Yugoslav territory left deep traces of interstate relations between the countries in the region within the region. "The leading actors of the international community, and above all the European Union and the United States, have fully supported the normalization of relations between newly born states and entities since the end of the armed conflicts in the former Yugoslavia. Therefore, during the past fifteen years of fullness, one can notice the gradual transition of the Western Balkans from the armed conflict zone, the over region in which the democratic, economic and security situation is stabilized in the region, all countries are unambiguously oriented towards accession to the European Union. This means that the countries of the region in the perspective are ready to accept a number of European values - peace, democracy, human and minority rights, the principle of equality and the principle of solidarity. "2

Since the situation in the Western Balkans has gradually stabilized, the need for the countries of the region to take greater or fuller responsibility for the functioning of multilateral forms of cooperation, which have been under the auspices of the international community over the past decade. All the countries of the Western Balkan, with the exception of the Republic of Serbia, are clearly defined for membership in the North Atlantic Treaty Organization (NATO). This has created a completely new geostrategic environment in the Western Balkans, since all countries from these territories, excluding Bosnia and Herzegovina, Macedonia, Serbia and Montenegro, have already become members of this military alliance. It is also important to point out that Bosnia and Herzegovina and the Republic of Montenegro will probably soon become members of the North Atlantic Treaty Organization.

Membership in the European Union is one of the priorities and strategic goals of most of these countries. There is a paradox regarding EU enlargement policy. On the one hand, there is a widespread belief (both at the professional level and at the political level) that it is one of the most successful and effective policies of the Union. The realization of this policy was of key importance for the stabilization of the European continent (formerly for the countries of the south-former right dictatorship, then for the countries of eastern and central Europe - the former socialist country), as well as for strengthening the international influence of the EU and positive economic trends on the continent. However, one of the problems is the membership of the countries of the Western Balkans. The Balkans has long been a zone of second-rate interests of

\footnotetext{
${ }^{2}$ Đukanović, D., International Politics and International Relations, Annual FPN, Faculty of Political Science, Belgrade, 2009, p. 12.
} 
the EU, beyond the countries of Central Europe and behind some Mediterranean countries. This approach has changed only in the last years of the twentieth century for two reasons: because of the possibility of expanding the EU to the east, which made the Balkan countries become direct neighbors, and because of the conflict in Kosovo and its effects on the security of the region.

The Stabilization and Association Process (PSP) is a special kind of regional approach for the Western Balkan countries. Albania, Bosnia and Herzegovina, the Republic of Macedonia, Serbia and Montenegro for the first time have been given the opportunity to become full members of the Union on the basis of their customized approach. In this way, the fate of the more successful states in this process is not conditioned by the position of the region as a whole. Starting the stabilization and association process towards the countries of the Western Balkans in 1999, in the conditions of the drastic lagging behind of these countries and in the conditions of the unwillingness of the EU countries to engage more quickly in this process, it points to the long-term period of the EU's accession to the Western Balkans for a decade or two.

The 1996-1999 regional approach did not yield adequate results because the EU measures were not adequate in relation to the size of economic, political and social problems in the Western Balkans region. This has been drastically shown in cases of $\mathrm{BiH}$, Kosovo, Albania, etc. The main result of the development of the post-crisis space on the territory of the former Yugoslavia is the fragmentation of formerly federal space into mini-states, in the majority of which there is no stability of political institutions of power. The contemporary Balkan crisis has shown that the diplomacy of most countries was very often unprofessional, and international organizations were powerless and that international law was not sought. The only interest and power played a vital role, and the settlement of all inter-ethnic issues did not arise until the situation and resolving of all inter-ethnic issues were made. From the above, it can be concluded that the path of the Western Balkan countries towards the EU can be traced in two phases - the accession process and the accession process. After 2003, all the countries of the Western Balkans managed to secure the status of candidates or the status of potential candidates for membership in the Union.

\subsection{Foreign Policy and European Integration of the Republic of Serbia}

The political public can hear remarks that it is not clear what the strategy of Serbian foreign policy is. The fact is that the modern world is extremely dynamic, and that the very environment of our country is in constant change, so it is clear that the republic of Serbia is determined in relation to The European Union, NATO and the immediate neighborhood in the region of Southeast Europe. This cannot be achieved without defining Serbia's relationship with the leading countries in the world (the United States and the Russian Federation), but also 
without empowering multilateral co-operation. Improving and strengthening Serbia's status in international organizations is also one of the leading goals. ${ }^{3}$

The goals of our country's foreign policy are based on the aspirations of the country to join the European Union and the North Atlantic Alliance, to strengthen regional cooperation and bilateral relations with its neighbors, then to develop balanced relations with global foreign policy actors (the United States and the Russian Federation), as well as to foster relations for the countries " Third World ", i.e. developing countries. However, the lack of a clearly defined foreign policy strategy in Serbia may pose a problem for further European / Euro-Atlantic integration of the country.

"It is evident that there is an extremely broad social consensus in Serbia regarding the country's entry into the European Union, but there is evidently no similar approximation of NATO accession. And in relation to Serbia's relations with the great powers there is a significant disagreement between political entities. On the one hand, there are political options that advocate strengthening the partnership with the leading world of the world - the United States, while, on the other hand, there are those who are in favor of balancing relations with this country, the Russian Federation and the People's Republic China." In Serbia, the most common are the "pillars" of foreign policy, which are mainly related to preserving the constitutional order of the country, including the preservation of Kosovo within Serbia, integration into the European Union, strengthening of good neighborly relations in the region of Southeast Europe and balancing relations with The United States and the Russian Federation. However, the layout of these "pillars" of foreign policy is very often changing.

\subsection{International Position and Euro-integration of Montenegro}

By adopting the Declaration of Independence in the Parliament of the Republic of Montenegro on June 3, 2006, after the referendum on May 21, the Government of the Republic of Montenegro took over the powers of establishing and conducting the foreign policy of the state of Montenegro as an independent international legal entity. Montenegro recognized in good time that good neighborly relations and integration are a guarantee of its successful development. Montenegro, as an independent state, has the opportunity to strengthen its position on the international scene and to dynamics and further improve relations with its most important actors. Accordingly, the Government of Montenegro has established the following foreign policy priorities: 1. Integration into the European Union and the North Atlantic Treaty Organization -

\footnotetext{
${ }^{3}$ Nešković, S., Lobbying and action of interest groups in the European Union with special reference to Serbia - case study, Proceedings no. 18. "Education and social development of Serbia with emphasis on Bor and Eastern Serbia", Belgrade: Center for Strategic Research on National Security - CESNA B Belgrade and Technical Faculty in Bor, University of Belgrade, 2016, p. 48.
} 
NATO, 2. Improving and maintaining good neighborly relations and regional cooperation, 3. Developing bilateral and multilateral cooperation. Montenegro's strategic goal is membership in the European Union. Montenegro sees the EU as the best framework for further development of overall reforms, adaptation to European standards and their adoption, as well as the improvement of bilateral relations with the members of the Union.

In Montenegro, there is a comprehensive agreement on the need for EU integration, which gives an additional impetus for accelerated progress towards this goal. The speed of progress in integration will depend on the dynamics of economic, political, judicial, security and overall reforms, i.e. from the speed and degree in which society as a whole will be engaged and reformed. In the foreign policy context, a regular political dialogue between the CG and the EU plays a particularly important role, as well as the long-term harmonization of foreign policy with the EU's common foreign and security policy. NATO membership is the second strategic foreign policy goal that is equally important, which is realistically achievable in a shorter period of time stability and security required to achieve other strategic goals such as joining the EU. Expectations are that accession to this organization will accelerate EU membership. The integration of Montenegro into NATO is closely linked to EU integration, because it is about two parallel and compatible processes.

Montenegro's strategic integrative goals - joining the EU and NATO - cannot be achieved without an active role in regional cooperation, the development of good neighborly relations and policy-making in a regional context. With all the countries of Southeast Europe, the goal is to develop good relations and communication with mutual respect and constant construction of political, economic, security, cultural, scientific contacts and cooperation and extremely important infra-structural connection. With these countries, Montenegro does not only share the same geographical area, but also the same foreign policy objectives. So far, more than 150 countries have recognized Montenegro and diplomatic relations have been established as well, and a considerable number of embassies in Podgorica have been opened, and the diplomatic and consular network of Montenegro in the world has been expanding. Strengthening economic cooperation with foreign partners through strengthening the economic dimension of diplomacy is one of the key activities on the international level. Strengthening bilateral relations at all levels creates favorable conditions for more content, richer and more intense communication with the diasporas. 4

In the context of strengthening bilateral relations, the priorities are: strengthening relations and cooperation with the EU's influential countries, as key partners in international organizations and on the international political scene, is an important factor for achieving Montenegro's foreign policy goals, as well as for its internal development. Overall cooperation

\footnotetext{
${ }^{4}$ Nešković, S., External Security Policy of the European Union and the Position of the Republic of Serbia - Case Study, Belgrade: Center for Strategic Research on National Security - CESNA B and Technical Faculty of Bor, 2016, p. 35 .
} 
with these countries through permanent bilateral contacts, but also through the processes of European and Euro-Atlantic integration, contributes to the economic and democratic progress of Montenegro and helps the dynamics of integration. Relations with the United States are of particular importance for Montenegro. Given that the United States is the most important ally in the North Atlantic Alliance and the inevitable partner of the EU, as well as the region, and have an extremely important role in all relevant international organizations, it is logical that Montenegro devotes a significant part of foreign policy to developing and strengthening partnership relations with the US. Historical and cultural relations strengthened by mutual understanding on the political plane, speak about the importance of constant improvement of cooperation between Montenegro and the Russian Federation. Strengthening further relations with Russia, in all areas at the bilateral level and within international organizations, contributes to the integration goals of Montenegro.

\subsection{Foreign policy of Bosnia and Herzegovina}

"The Constitution of Bosnia and Herzegovina lists exclusively institutional frameworks for conducting foreign policy, but it does not indicate certain priorities and directions of the country's participation in contemporary international relations. On the basis of the constitutional authority and in connection with the conduct of foreign policy, the members of the Presidency of Bosnia and Herzegovina in 2003 established "General directions and priorities for the implementation of BiH's foreign policy". This implies a lot of compliance with the generally accepted principles of international law and respect for concluded and ratified treaties. In this regard, it is stated that openness and equality, mutual respect for sovereignty and territorial integrity, principles of peaceful co-operation, constructive dialogue, the fight against terrorism and organized crime and respecting the basic principles of BiH's foreign policy. Starting from the principles already outlined, the Presidency Bosnia and Herzegovina precisely defined the priorities of the country's foreign policy. These are the preservation of the country's insecurity and territorial integrity, the implementation of the General Framework of the Peace Agreement in $\mathrm{BiH}$, the accession of the country to the Euro-Atlantic integration processes, the country's participation in multilateral activities and the promotion of the state as a partner in international economic relations with the aim of achieving full membership in the World Trade Organization". 5

In creating foreign policy, the $\mathrm{BiH}$ Presidency has come from the fact that the world is affected by the process of globalization, which structurally changes international relations and calls for the resolution of burning issues at global and regional levels in order to comprehensively protect human rights, eliminate poverty, develop a global partnership for development, a firm commitment to the processes of integration and transition in the region of Southeast Europe in the political, economic and security sense. Bosnia and Herzegovina's

\footnotetext{
${ }^{5}$ Đukanović, D., Foreign Policy Orientations of the Western Balkan Countries: Comparative Analysis, Annual FPN, Faculty of Political Science, Belgrade, 2010, p.301.
} 
foreign policy is aimed at improving and preserving lasting peace, security and stable democratic and overall state development, that is, inclusion in contemporary European, political, security integration flows. The priorities are as follows: 1. Preservation and protection of BiH's independence, sovereignty and territorial integrity within internationally recognized borders, 2 . Complete and consistent implementation of the General Peace Agreement, 3. Accession to EuroAtlantic integration processes, 4. Participation of $\mathrm{BiH}$ in multilateral activities, especially as part of the UN system, the Council of Europe, the Organization for Security and Co-operation in Europe, etc. 5. Promote $\mathrm{BiH}$ as a partner in international economic relations and activities that will enable its admission to the World Trade Organization and other international organizations and associations.

On a bilateral level: Improving cooperation with neighboring countries, with member states of the Steering Board of the Peace Implementation Council, the United States, the Russian Federation, Great Britain, France, China and other members of the UN Security Council, EU Member States, member states of the Organization of the Islamic Conference and other countries that contribute to the renewal and development of Bosnia and Herzegovina. BiH will pledge to establish diplomatic relations with the countries with which they have not yet been established, with a special emphasis on bilateral relations with the countries of the region of Southeast Europe. Also, the need for achieving interstate agreements is emphasized, especially in the areas of economy and foreign investment. The main goals of the country's foreign policy are, as stated in the same document, the promotion of the economy, as well as the development of cooperation in the field of science, technology, culture, education and sports.

On the other hand, within the framework of multilateral forms of cooperation, it is insisting on strengthening the position of Bosnia and Herzegovina in the geo-strategic sense and its membership in European and Euro-Atlantic integrations. Although seven years have passed since the adoption of this document, due to numerous internal problems in the country, to significant progress in improving the country's foreign policy position. However, it is evident that there has been some progress in the process of joining the European Union, and in particular NATO. In the meantime, BiH's relations with neighbors have consolidated, but also strengthened forms of multilateral regional cooperation. On the other hand, no progress has been made regarding the country's accession to the WTO, and there has been no improvement in bilateral relations with the leading countries of the world (USA, the Russian Federation and the People's Republic of China). The fact is that only citizens of $\mathrm{BiH}$ and Albania still have a rather rigorous Schengen visa regime. The two-entity $\mathrm{BiH}$ does not have a broader consensus on NATO membership, which is particularly noticeable in the Republika Srpska.

\subsection{The international position of Northern Macedonia}

In February 2019, Northern Macedonia officially proclaimed the current name internationally recognized. After declaring independence in late 1991, it was mainly focused on consolidating internal interethnic and political circumstances in the country. The 1991 
Constitution of Macedonia, which was substantially amended by the amendments of the beginning of this decade, contains a chapter devoted to international relations in the Constitution of Macedonia, but it does not specify in detail the general direction of the country's foreign policy activities. In 2009, within the Ministry of Foreign Affairs of Macedonia, an internal document titled "Objectives and Priorities" was adopted internally. The document identifies the country's commitment to European and transatlantic integration. It was pointed out the necessity of completing the procedure regarding the acquisition of full membership in NATO, the start of negotiations on membership with the European Union, the abolition of visas for Macedonian citizens, the settlement of the name of the country with the southern neighbor - Greece, and the strengthening of economic and public diplomacy. ${ }^{6}$

As one of the leading priorities, strengthening the strategic partnership with the US is also developing a comprehensive partnership with the EU and NATO. At the same time, it is pointed out the necessity of cooperation with the Russian Federation and the People's Republic of China. The importance of the development of good neighborly relations with the countries in the region was also emphasized. Therefore, the construction of security, stability and cooperation represents a very important activity in the foreign policy of Northern Macedonia, both bilaterally and on a multilateral basis, and therefore it will aim for more significant participation in all global and regional organizations. This also implies an international fight against global security challenges - terrorism, organized crime and corruption, and the like.

Promoting the economic potentials and possibilities of Northern Macedonia, preserving the sovereignty, stability and security of the state, as well as affirmation of the national cultural and spiritual identity, are also the foreign policy priorities of the country. The care for members of the Macedonian community outside the country of origin is, as stated in this document, one of the important goals of foreign policy. "Unlike other strategic foreign policy documents of the Western Balkans countries, the goals and priorities of the Republic of Macedonia's policy are the review of the attitude in relation to current international problems. This document therefore contains the views of the Ministry of Foreign Affairs of Northern Macedonia regarding the enlargement of the European Union, international terrorism, as well as the situation in Afghanistan, Pakistan, Iraq and Iran. At the same time, considerable attention is paid to the problems of Taiwan and the territorial integrity of the People's Republic of China, the nuclear weapons of North Korea, the development of the Middle East crisis and the situation in Sudan, the crisis in Georgia, or the postponement of the captured regions of Abkhazia and South Ossetia. ${ }^{7}$ "In the past ten years, Northern Macedonia has managed to make some progress in terms of NATO membership and the abolition of visas for its citizens. It has done a lot in connection with strengthening the strategic partnership with the USA and intensifying good

\footnotetext{
${ }^{6}$ Nešković, S., External Security Policy of the European Union and the Position of the Republic of Serbia - Case Study, Belgrade: Center for Strategic Research on National Security - CESNA B and Technical Faculty of Bor, 2016, p. 36.

${ }^{7}$ Đukanović, D., Foreign Policy Orientations of the Western Balkan Countries: Comparative Analysis, Annual FPN, Faculty of Political Science, Belgrade, 2010, p. 308.
} 
neighborly relations in Southeast Europe. Definitely in February 2019, the dispute with Greece over the name of Macedonia ended, which greatly facilitates the normalization of the bilateral relations of these two countries, as well as the issue of the accelerated accession of this country to NATO and the European Union.

\subsection{The concept of foreign policy of the Republic of Albania}

In 2005, the Assembly of the Republic of Albania adopted the Program of the Government for the period from 2005 to 2009. Within this document it is emphasized that Albania's membership in the European Union and NATO are two of the most important foreign policy priorities, and that, In this regard, it is necessary for all stakeholders in the country to be involved in the realization of the stated goals. The government therefore committed itself to implement and coordinate internal reforms in order to successfully complete the European integration. It is said that Albania should lead a pragmatic and realistic foreign policy, and it is especially important to ensure the possibility of increasing the volume of foreign investment. In international organizations, whose member Albania is, it is necessary to promote a new image of the country. Particular importance will be given to cultural diplomacy and bilateral cooperation with all democratic countries of the world. And relations with the United States are of strategic importance to Albania in the fields of economy, security and democratic consolidation.

"It is also noted that Albania will promote peace and stability in the region of Southeast Europe through the strengthening of political, diplomatic and cultural cooperation, where the conclusion of bilateral agreements with the countries of South-Eastern Europe should also play a significant role. In this document, Albania's friendship with Turkey is particularly emphasized. One of the important goals is also the establishment of better bilateral relations with the EU member states, so Albania will seek to establish better relations with Germany, France and Great Britain, as well as with Austria. The development of Albania's economic and political relations with Japan, India and Canada, as well as stronger economic and cultural cooperation with the People's Republic of China, is also listed as foreign policy priorities. Albania will best safeguard its national interests through membership in the North Atlantic Treaty Organization, It is highlighted in the Government's Program (2005-2009), but the country will actively engage in the work of regional security and defense forums - primarily within the framework of the Adriatic Charter Agreement and the South East Europe Co-operation Initiative for Southeast Europe - SEDM. "8

Like all the countries of the Western Balkans, Albania has managed to make significant steps in European integration. Also, the Stabilization and Association Agreement entered into force. But, despite all of this, Albanian citizens still cannot travel to EU countries without visas. The great success of Albania's foreign policy was achieved in 2009 by joining NATO, and the relations between this country and the United States are continually rising. When it comes to

${ }^{8}$ Đukanović, D., Foreign Policy Orientations of the Western Balkan Countries: Comparative Analysis, Annual FPN, Faculty of Political Science, Belgrade, 2010, p. 309. 
cooperation with the countries in the region, there is a certain relaxation in bilaterally relations with Serbia, which were burdened with the official Tirana's attitude towards the Kosovo crisis. With other Western Balkan and Southeast European countries, Albania has no open issues, which is also stated in the Government's program document.

\section{SECURITY OF THE WESTERN BALKANS COUNTRY}

The term Western Balkans is most often understood as the countries of the former Yugoslavia - Albania, Macedonia, Serbia, Montenegro, Bosnia and Herzegovina, and less often Croatia and Slovenia. Thanks to the turbulent past, this region is today a mixture of different cultures. In this space, the first civilizations that formed today's world were created. This part is abundant with many natural resources, so tourism is one of the important branches in the countries of this region. ${ }^{9}$ This area represents the shortest connection between Europe and Asia, whether it is road, river or air traffic. The Western Balkans is one of the main transit parts of Europe and because of its geographical position that allows Europe to be open to Southeast Asia, Asia Minor to North East Africa. Poorly developed economies and higher share of agricultural population than in other European countries are largely due to frequent internal conflicts and wars. This part of Europe is synonymous with backwardness in the economy, and the label "barrel with gunpowder" received the most tragic confirmation in the wars of the early 1990s on the territory of the former Yugoslavia. ${ }^{10}$

The countries of the Western Balkans have been in the process of transitional changes in the last twenty years. Although the region is still the main challenge for institutional and structural reforms, positive macroeconomic characteristics are visible in the region. The biggest problems in the region are still political instability and large external imbalances (balance of payments deficits in all regions of the region are at a fairly high level). It is characteristic for all Western Balkan countries that these are mainly small economies, have insufficient compliance with European and international standards and standards (although this harmonization process is ongoing), that their products are not sufficiently competitive, that all countries have a trade balance deficit, and budget. All countries, more or less, have unsatisfactory infrastructure, lack of working capital and insufficient and inadequate credit support, high participation of the gray economy, and still more significant corruption and crime.

The economic structure dominates the participation of mining, industry, agriculture and forestry, while the service sector is underdeveloped, which also affects the structure of foreign trade. On the export side dominated by agro-food products, industrial raw materials and semifinished products, and on the import side of machines, equipment and industrial products of high

\footnotetext{
${ }^{9}$ Nešković, S., European Integration and Tourism Development in the Countries of South-East Europe, International Conference Contemporary Trends in Tourism Development, Proceedings, Travnik: International University of Travnik, 28-29. March 2013, p. 34.

${ }^{10}$ Nešković, S., Foreign Policy Orientation and Security of the Western Balkans, New Challenges to the Balkan Security, Vol. 2, Thematic Collective Book, Veliko Turnovo, St. Cyril and St. Methodius University, 2015, p. 15.
} 
degree of processing. In economic cooperation with foreign countries, these countries are primarily oriented towards cooperation with the industrialized countries of the West, especially with the EU. Entering the European Union is one of the most important priorities of each of the countries in this region. The national wealth of the Western Balkans is significant, especially in the production of agricultural products, and there are great chances for the development of animal husbandry, especially mountain and mountain, which is considered an ecologically clean environment in this region. There are exceptional chances for healthy food production: meat, cheese, leather, wool, and others. In addition to agriculture, development chances exist in: black and non-ferrous metallurgy, chemical industry, leather industry, footwear and textiles. Cooperation and harmonization of development and joint approach to third countries is of great importance for the further development of this area. Of course, the development of this region is not possible without well-developed infrastructure and road networks. The advantages of a unique geopolitical position would be much better used with the developed road network and communications, and would significantly influence the integration of the countries of this region in the EU. ${ }^{11}$

\subsection{Security Policy of the European Union}

The geopolitical changes that occurred in the late 1980s and early 1990s in the 20th century; the collapse of communism, the end of the Cold War, the unification of Germany, the collapse of the Soviet Union, the beginning of the conflict in the former SFRY territory motivated the member states of the then European Union to make an effort in order to make the future of Europe in the field of foreign and security policy unique, decisive and in line with the character that it had as a trade and economic power. The Treaty of Maastricht, which came into force in 1993, established the EU, and its policies were divided into so-called. Three pillars. The EU's common foreign and security policy is also called the "second pillar of the EU". ${ }^{12}$

According to the Treaty of Maastricht, the EU defines and applies the CFSP, which covers all areas of foreign and security policy, the goals of which are to preserve common values, the fundamental interests of the independence and integrity of the Union in accordance with the principles of the UN Charter, increasing the security of the Union in all respects, peace and international security in accordance with the principles of the UN Charter, the Helsinki Final Act and the objectives of the Paris Charter, including those related to external borders, the promotion of international cooperation, the development of democracy and the rule of law, and respect for human rights and fundamental rights freedom. In 1996, at a NATO ministerial meeting in Berlin, an agreement was reached on the creation of a European NATO pillar. Thus,

\footnotetext{
${ }^{11}$ Nešković, S., Traffic corridors in the function of the progress of the countries of Southeast Europe, International conference Mobility and safety of road transport, Proceedings, Travnik: International University Travnik, 30-31. May 2013, p. 21.

${ }^{12}$ Nešković, S., Jovanović, Ž., Ecological Paradigm Within the Context of the International Policy - Development Study, Balkan Journal of Philosophy, Vol. 8, Bulgarian Academy of Sciences, 2016, p. 13.
} 
this, the so-called. By the Berlin Agreement, EU countries are enabled, through the Western European Union, to act independently of the NATO military assets with military means, but to have the capability to use NATO capacity if there is a need for this. In 1997, the Treaty of Amsterdam included the so- Petersburg tasks, including: humanitarian and rescue tasks, peacekeeping tasks and crisis management tasks, including peacekeeping. The 1998 position that the EU must have the capacity to carry out autonomous actions - supported by credible military forces - was confirmed at the European Council meeting in 1999 when it was adopted.

The leading goal from Helsinki, which was the first concrete step towards strengthening the EU's military capabilities. It contained the desired (planned) size of the EU's military capacities to be achieved by 2003. In 2002, the so-called Berlin plus an agreement representing a package of agreements between NATO and the EU (i.e., it was a modification and amendment to the Berlin Agreement of 1996). It allows the EU to use military capabilities of NATO in the conduct of its own operations, but with respect to certain procedures. In 2003, at the European Council meeting in Brussels, the European Security Strategy was adopted, and in 2004 at the European Council meeting, as a further step in the development of the EU's military capacities, the so- The main goal of the 2010 European Security Strategy (ESB) was adopted at the European Council meeting in Brussels in December 2003, and its full title is "A European Security Strategy - a Safer Europe in a Better World". For the first time since its inception, the European Union presented and defined its own security strategy in one place. Through four chapters of the strategy, the European Union has analyzed the most important security threats, presented its strategic goals, emphasized the need to modernize its resources, the way it functions and cooperate with partners in addressing security issues.

The European Union believes it belongs to the role of a global player. This assessment is based on the total number of associated EU Member States, the number of inhabitants, the share in total world production and the numerous instruments and resources available to address security issues. In order to achieve and protect its interests, the EU has opted for peaceful action and problem solving, with a common co-operation with existing international institutions and countries. The first chapter is devoted to identifying the security challenges and threats that the EU faces. War, poverty, disease, state competition for natural resources and dependence on energy (water, oil and gas) are recognized as global challenges. The key threats are classified: terrorism, the proliferation of weapons of mass destruction, regional conflicts, failed states and organized crime. In the second chapter, the European Security Strategy has considered the European Union's strategic objectives and presented the activities carried out by the European Union in the previous elimination of threats and its views and attitudes in resolving security issues.

The traditional concept of self-defense by the European Union against the threat of an armed invasion on it has been replaced by a new one. Due to the emergence of new threats, the first line of defense has been shifted beyond the borders of the EU. The emergence of threats that are more diverse, less visible, and less predictable, compared to the Cold War period, have led 
the Union's readiness to react before the crisis itself and the problem arise at its borders. In order to properly respond to these new threats, the EU had a wide range of necessary military and nonmilitary instruments. The Union also sought to build a stable security environment. The interests of the EU are to have stable and accountable states at its borders. With each enlargement, the Union changed and expanded its borders, and thus increasingly approached security and problem areas. Therefore, the EU intended to create a "ring" of stable countries in its surroundings especially in Eastern Europe and the Mediterranean. Without the intention of creating new dividing lines, Europe is striving to create stable countries by developing their own development and eliminating potential hot spots for the emergence of security threats that could threaten the EU.

In the last part of the European Union, its efforts in international politics focused on the establishment of an effective multilateral system - the development of a strong international community, functional international institutions and international law. The UN is recognized as the bearer of international changes, alongside existing international trade and financial institutions. The development of the multilateral system gives the developed transatlantic relations, reflected in NATO, and numerous regional organizations. The European Union itself is ready to help many countries left excluded from the international system by assisting them in returning among other countries of the international community. The third chapter of the European Security Strategy points to the need to modernize the EU, what else the Union should do to use all its potentials in achieving strategic objectives and countering threats. In order to achieve the set goals and implement the set tasks, the EU must be more active, more capable, more co-ordinates and cooperate with other partners. Basically, it ends with the emphasis on the necessary Union cooperation with partners. The European Security Strategy is a comprehensive strategic framework of the European Union in the field of security. The EU has taken a serious step in the implemented of the security policy. At the same time, this document provides a vision of the role of the European Union in the world, as well as an analysis of the existing security threats, the strategic goals it seeks, and recommendations that Member States should accept in order to better and more efficiently implement the European security policy. As the main determinants of the ESB we can distinguish: Global responsibility of the EU, Effective multilateralism, Preventive action, Stable security environment, Maintaining a transatlantic partnership and cooperation with the USA, Establishing a list of key EU security threats. ${ }^{13}$

The common and common values of all European countries are: democracy, market economy, rule of law and respect for human freedoms. Likewise, the attitude of all EU members, without exception, considers that European security is indivisible, that is, the security of each country depends individually on the security of the environment. From the above it follows that

\footnotetext{
${ }^{13}$ Nešković, S., Geostrategic Position And Security Synergies of the Black Sea Region Through Cooperation with the European Union, Cross - Border Book Series "New Challengs to Security and Development of the Balkans" Vol. 5, Cross - Border Cooperation, Security and Development Perspectivies of the Wider Black Sea Region, St. Cyril and St. Methodius University of Veliko Turnovo, Bulgaria, 2018, p. 28.
} 
regional and general European security is the interest and concern of all European countries, and cooperation, linking and jointly confronting security challenges, risks and threats is imperative for both the Western Balkans and Europe as a whole. For most Western Balkan countries, the economic factor is the biggest motivator which motivates them to the EU. However, in order for integration to be of high quality, it is necessary to respect safety standards, to resolve disputes peacefully, democratic control of armed and security forces. Peace and stability are a prerequisite for joining the countries of the Southeastern EU region. Therefore, the countries of this region are instructed to work together in combating all negative processes that jeopardize their security.

Although after the conflict in the EU, the EU initiated initiatives such as the Stability Pact and the Stabilization and Association Process with the countries of the region, the rhythm of change is not fast enough. Insufficient cooperation and very slow integration of the countries of this region with the EU have a long-term negative impact on their economic, scientific and technological and all other potentials and, consequently, their competitive position. Countries in the region believe that the road to EU membership is getting longer and more uncertain, and are frightened by the increase in fatigue from the enlargement of the European Union. Also, there is a lot of uncertainty about the EU's engagement in Kosovo and Metohija, and the consequences of the current economic crisis should not be neglected, the consequences of which will be long and difficult and will significantly affect all aspects of European integration. The problem of bilateral relations and the historical heritage of the Western Balkan countries also slow down the integration process. Another in a series of problems is the different presence and status of NATO in certain countries of this region. On the other hand, the approval of the candidate status of Serbia and Montenegro, the Association Agreement and Stabilization of $\mathrm{BiH}$, as well as the abolition of the visa regime for the countries of the region, confirms the belief that the Western Balkan countries - belong to Europe.

\section{CONCLUSION}

The region of the Western Balkans represents a kind of ambience, characterized by a heavy century heritage, but also events from a close past. The security research of this region is very current, because due to modern challenges, risks and threats, it is difficult to predict potential consequences for the countries of this region. When looking at the position of the states in a conspicuous international relationship, the most important thing is that there is a certain predictability of their actions in the framework of the multi-lateral and multilateral relations at the regional and global level. That is why the adoption of an external policy strategy is essential for defining the goals and tasks of the state's external action. The foreign policy strategy of the territories of the Western Balkans must be long-term or time-bound by the country's entry into wider integration. It is therefore important that the countries of this region define their own political strategy in relation to EU and NATO membership, and improve relations with neighbors, build a better relationship with the EU, and strengthen the role of these countries in 
international organizations. At the same time, most countries in the Western Balkans are also pushing for the promotion of their own economy and overall identity in the world.

Speaking about the military-political stabilization and security of the Western Balkans, a special challenge is the slowed European integration, the NATO enlargement process, the new positioning of Russia in the region and the new US concept in this part of the world. Although relevant international factors publicly emphasize the importance of co-operation and dialogue, their role in this region is very often contradictory and undefined. On the one hand, the European Union's firm resolve to strengthen its own security identity, on the one hand, increased the political and military autonomy of the United States against NATO, as well as the new need of the Russian Federation to position itself in the region. Conflicts and different perceptions regarding the resolution of important issues and problems in this part of Europe are very pronounced among them. It can be noted that in the short term, none of the relevant international actors wants a new civil conflict in this region, which characterized this area at the end of the 20th century, but nevertheless, there is the attitude of all of them about the need to retain international forces in this region.

\section{LITERATURE}

1. Bzezinski, Z., Great chess board, CID, Podgorica, 2011.

2. Đukanović, D., International Politics and International Relations, Annual FPN, Faculty of Political Sciences, Belgrade, 2009.

3. Đukanović, D., Foreign Policy Orientation of the Western Balkan Countries: Comparative Analysis, Annual FPN, Faculty of Political Science, Belgrade, 2010.

4. Helcl, J. European Security Policy in the Function of Strengthening the EU, Belgrade, Military Work, 2009/4.

5. Kissinger, H., Does the US need foreign policy- to meet 21 st century diplomacy, BMG, Belgrade, 2003.

6. Konjikovac, M., The Impact of Relevant International Subjects on Security of Southeastern Europe, Belgrade, Military Work / Winter, 2011.

7. Lisanin, M., Cupać, B., Russia, NATO, EU: Complementary or Competing Views on the New Security Architecture of Europe, Belgrade, Military Work / Spring, 2013.

8. Nešković, S., European Integration and Tourism Development in the Countries of SouthEast Europe, International Conference Contemporary Trends in Tourism Development, Travnik: International Travnik University, 28-29. March 2013.

9. Nešković, S., Traffic corridors in the function of the progress of the countries of Southeastern Europe, International conference Mobility and safety of road transport, Travnik: International University Travnik, 30-31. May 2013. 
10. Nešković, S., Means of international politics with a special emphasis on economic resources, International politics, Belgrade: Institute for International Politics and Economy, 2013.

11. Nešković, S., Economic Diplomacy and Legislation of the States of South-East Europe in the Context of European Integration, Proceedings of the Works no. 10, International Conference "Legal and Economic Aspects of the Concept of Integration of the Countries of Southeastern Europe in the EU with a Special Focus on Bosnia and Herzegovina", Travnik: International University of Travnik, Travnik, Bosnia and Herzegovina, 2014.

12. Nešković S., Foreign Policy Orientation and Security of the Western Balkans, New Challenges to the Balkan Security, Vol. 2, Thematic Collective Book, Veliko Tarnovo, St. Cyril and St. Methodius University, 2015.

13. Nešković, S., Business Diplomacy and Legal Regulations in the Context of European Integration of the Republic of Serbia, Proceedings no. 15. "Serbia on the Road to the European Union", Belgrade: Center for Strategic Research on National Security CESNA B Belgrade, 2015.

14. Nešković, S., Lobbying and action of interest groups in the European Union with special reference to Serbia - case study, Proceedings no. 18. "Education and social development of Serbia with an emphasis on Bor and Eastern Serbia", Belgrade: Center for Strategic Research on National Security - CESNAB Belgrade and Technical Faculty in Bor, University of Belgrade, 2016.

15. Nešković, S., Foreign Security Policy of the European Union and the Position of the Republic of Serbia - Case Study, Belgrade: Center for Strategic Research on National Security - CESNA B and Technical Faculty of Bor, 2016.

16. Nešković, S., Geostrategic Position and Security Synergies of the Black Sea Region through Cooperation with the European Union, Cross-Border Book Series "New Challenges to the Security and Development of the Balkans" Vol. 5, Cross-Border Cooperation, Security and Development Perspectivies of the Black Sea Region, St. Cyril and St. Metodij University of Veliko Turnovo, Bulgaria, 2018.

17. Nešković, S., Ketin, S., Šećerov, P., Đelić, T., A., International Politics and Ecology: A Focus on Environmental Protection, Frensenius Environmental Bulletin - FEB, Vol. 27. No 11/2018.

18. Noetzel, T and Scheer, N., Does a multi-tier NATO matter ?, International Affairs, Vol 85, 2009.

19. Ristic, T. Transatlantic relationship and design of the international system after the Cold War, ISA, Belgrade, 2010.

20. Spykman, N., The Geography of the Peace, Harcourt, Brace \& Co. New York, 1994. 